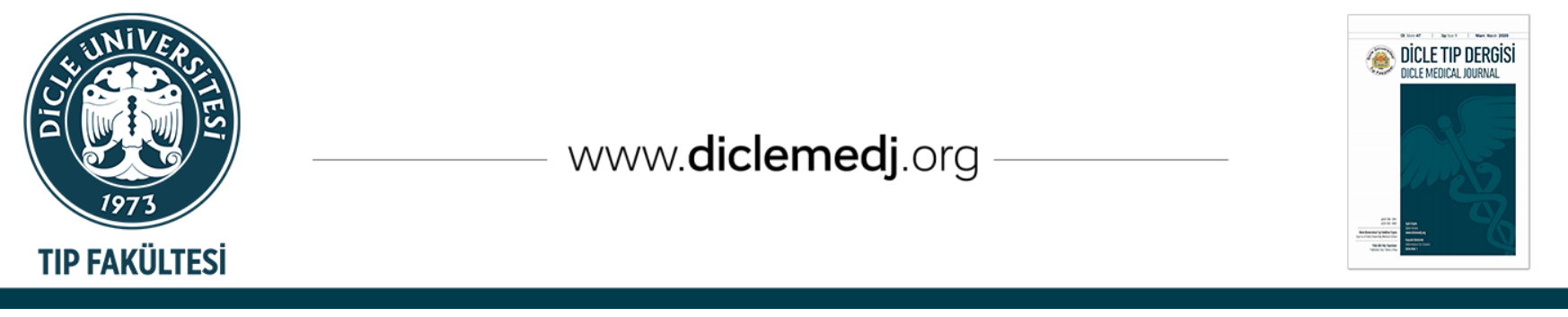

Original Article / Özgün Araştırma

\title{
The Long-Term Effect of Very Low Birth Weight and Prematurity On Bone Mineral Density In 5-7 Years Old Children
}

\author{
Fatma Demirbaş ${ }^{1}{ }^{1}$, Ayşe Engin Arısoy ${ }^{2}{ }^{2}$, Hakan Demir ${ }^{\text {D }} 3$ \\ 1 Department of Pediatrics, Kocaeli University Research and Application Hospital, Kocaeli, Turkey. \\ 2 Department of Pediatrics Neonatology, Kocaeli University Research and Application Hospital, Kocaeli, Turkey. \\ 3 Nuclear Medicine, Kocaeli University Research and Application Hospital, Kocaeli, Turkey.
}

Received: 25.03.2020; Revised: 04.06.2020; Accepted: 04.06.2020

\begin{abstract}
Objective: Very low birth weight (VLBW) infants are at increased risk of osteopenia of prematurity due to interruption of intrauterine bone mineralization. In this study aimed to evaluate the bone mineral density (BMD) by evaluating DXA in children aged 5-7 years with VLBW and preterm birth.
\end{abstract}

Methods: This study was conducted prospectively between February 2011 and September 2012. Seventy-five children aged 5-7 years, who were born under 1.500 grams were included.

Results: Bone density measurements of the study group (42 female 56\%) were found to be low compared to the DXA reference values ( $\mathrm{p}<0.001)$. According to the L1-L4 Z score, bone density was found to be low in $21.33 \%$ (n: 16) of the cases. Total femur Z score ( $p=0.018)$, femur neck BMD ( $p=0.001)$, total femur BMD $(p=0.012)$ values were significantly lower in females than males. Whole body BMD values $(\mathrm{p}=0.021)$ were significantly lower in patients receiving postnatal systemic steroids than in the non-receiving group. Femur neck BMD values of the patients who received only breast milk in the first six months were found to be statistically significantly higher than those who received only formula in the first six months $(p=0.034)$.A significant correlation was found between the current height, weight, BMI increase and BMD measurement.

Conclusion: In this study, it was shown that bone diseases in VLBW and preterm infants affect bone mineralization in long term. We determined the effects of drugs and nutrition used in treatments and current anthropometric measurements on bone health of preterm and VLBW.

Keywords: bone mineral density, osteoporosis, prematurity, very low birth weight

DOI: 10.5798/dicletip.

Correspondence / Yazışma Adresi: Fatma Demirbaș, Diyarbakir Pediatric Diseases Hospital, Pediatric Gastroenterology, Hepatology and Nutrition, Yenişehir Mah. Mimar Sinan Cad. No: 1521090 Yenişehir, Diyarbakır, Turkey e-mail: fatmademirbas81@hotmail.com 


\section{5-7 Yaş Arası Çocuklarda Düşük Doğum Ağırlığı ve Prematüretenin Kemik Mineral Dansitenin Üzerine Uzun Dönem Etkisi}

Öz

Giriş: Çok düşük doğum ağırlıklı bebekler, intrauterin kemik mineralizasyonun kesintiye uğraması nedeniyle prematüre osteopeni riski altındadır. Bu çalışmada çok düşük doğum ağırlıklı ve preterm doğan 5-7 yaş arası çocuklarda kemik mineral yoğunluğunun DXA ile değerlendirilmesi amaçlandı.

Yöntemler: Bu çalışma, Şubat 2011 ve Eylül 2012 arasında prospektif olarak gerçekleştirildi. Bin beş yüz gramın altında doğan 5 -7 yaş arası 75 çocuk dahil edildi.

Bulgular: Çalışma grubunun kemik yoğunluğu ölçümleri (42 kadın \%56) DXA referans değerlerine göre düşük bulundu (p <0,001). L1-L4 Z skoruna göre, olguların \%21,33'ünde düşük bulundu. Total femur Z skoru, femur boynu kemik mineral yoğunluğu, total femur kemik mineral yoğunluğu değerleri kadınlarda erkeklerden anlamlı olarak düşüktü(p =0,018, p=0,001, p=0,012, sırasıyla). Tüm vücut kemik mineral yoğunluğu değerleri $(p=0,021)$ postnatal sistemik steroid alan hastalarda almayan gruba göre anlamlı derecede düşüktü. İlk altı ayda sadece anne sütü alan hastaların femur boynu kemik mineral yoğunluğu değerleri, ilk altı ayda sadece formül alanlara göre istatistiksel olarak anlamlı derecede yüksek bulundu ( $\mathrm{p}=0,034)$. Güncel boy, kilo, vücut kitle indeks ile kemik mineral yoğunluğu ölçümü arasında anlamlı bir korelasyon vardı.

Sonuç: $\mathrm{Bu}$ çalıșmada çok düşük doğum ağırlıklı ve erken doğmuş bebeklerde kemik hastalıklarının uzun vadede kemik mineralizasyonunu etkilediği gösterilmiştir. Tedavide kullanılan ilaç ve beslenmenin ve güncel antropometrik ölçümlerin preterm ve çok düşük doğum ağırlıklı kemik sağlığına etkilerini belirledik.

Anahtar kelimeler: Çok düşük doğum ağırlık, kemik mineral yoğunluğu, osteoporoz, prematurite.

\section{INTRODUCTION}

In recent years, medical advances in prenatal care, assisted reproductive techniques, and neonatal intensive care units have increased the survival rate of preterm infants. Although the survival rates of infants with very low gestational age increased, there was no decrease in the main morbidity problems ${ }^{1}$. One of these problems is the metabolic bone disease of prematurity and early onset osteopenia and osteoporosis ${ }^{2}$. The $80 \%$ of maternal-fetal calcium phosphorus transport takes place within the third trimester' of intra-uterine life. Interruption of intrauterine bone mineralization in preterm and very low birth weight (VLBW) infants increases the frequency of osteopenia depending on prenatal (steroid use during pregnancy, diabetes, preeclampsia) and postnatal (use of surfactant, mechanical ventilation, duration of breastfeeding or formula feeding time, exposure to medications diuretic, theophylline, caffeine, aminoglycoside and time of total parenteral nutrition) reasons. Its effect on long-term bone health is not clear.
Preterm infants are at high risk in terms of bone mineralization and suboptimal growth when compared to term infants ${ }^{3-5}$. Different findings were obtained in the evaluation of bone density in the childhood age group of VLBW and preterm infants. Kurl et al. ${ }^{6}$ in their study of 6-7 years old children with premature birth found similar lumbar bone mineral density (BMD) and bone mineral content (BMC) compared to the reference group. However, Armstrong et al. ${ }^{7}$ reported very low lumbar BMD values of preterm children compared with term peers at the age of 6 to 7 years. However, it has been suggested that the delay in bone mineralization continues until 4-16 years of age ${ }^{8}$.

The prevention or treatment of premature osteopenia has favorable effects such as, linear growth, increment of maximal bone mass and avoidance of bone fractures and should not be neglected ${ }^{9-12}$.

The aim of this study is to interpret the bone mineral density in 5-7 years old children with premature and VLBW history by evaluating dual 
energy X-ray absorptiometry (DXA) and to determine the relationships of DXA with prenatal, natal, postnatal and current variables.

\section{METHODS}

This study was carried out between February 2011 and September 2012 with 75 children aged between 5-7 years who were born lower than 1500 gram and admitted in the neonatal intensive care unit (NICU) of University Hospital.

The patients' data files were examined for the age of the mother, steroid use during pregnancy, diabetes, preeclampsia, diagnosis of hypertension, smoking and whether or not mothers were used headscarf in pregnancy. The birth date, sex, gestational week, birth weight, type of delivery, intrauterine development (SGA, AGA, LGA) were ascertained. A history of early membrane rupture, presence of chorioamnionitis and prenatal steroid use, duration of hospitalization of a baby, presence of RDS (respiratory distress syndrome), use of surfactant, mechanical ventilation, intubation and duration of nasal ventilation, presence and degree of BPD (bronchopulmonary dysplasia) were determined.

Whether the baby was receiving systemic steroid treatment during hospitalization, and if so, the time and duration were recorded. Early or late, clinical or culture-proven presence of sepsis, presence of second stage or more necrotizing enterocolitis (NEC), accompanying patent ductus arteriosus (PDA), presence of intracranial hemorrhage (ICH), and presence of retinopathy (ROP) of prematurity were questioned.

The use and administration times of total parenteral nutrition (TPN), transitions to enteral feeding of infants were recorded throughout the stays at hospital.

Diuretic, theophylline, caffeine, aminoglycoside use in the treatment of patients; if used, the duration was learned from the hospital files. The information about the duration of breastfeeding or formula feeding time, vitamin $\mathrm{D}$ and drug use history of the children were obtained from their files and families.

The child's home and environmental living conditions, school attendance, active outdoor playtimes, daily milk consumption were asked. Percentiles and Z scores of weight, height, and body mass index (BMI) information of the patients were recorded.

USA-made LUNAR BRAND model of 2010, 8743 BX-1L (GE Medical System ${ }^{\text {TM }}$ ), DXA - dual energy X-ray absorptiometry device was used to measure bone density. All measurements were made by the same technician, all assessments were completed by the same nuclear medicine specialist based on source data schedules for children of device instruction manual. Total body (TB), total body less head (TBLH), L1-L4 vertebrae, femur neck and femur total bone mineral density (BMD) (gr/ $\left.\mathrm{cm}^{2}\right)$, bone mineral content (gr) and $\mathrm{Z}$ score of all cases were measured. In studies showed that the trabecular bone mineral changes are more sensitive than cortical bone. So it has been used as the lumbar zone measurement area $a^{6,7,13-16 .}$

As the DXA had very low dose of radiation and the control group did not benefit from the study, the experimental group was compared with the reference values of the DXA device as a control group. In patients with the BMD Z score between 0 and $-2,0$ was normal, of the cases with lower than $-2,0$ are categorized as "low bone density by chronological age" and "lower value than expected by age".

* Ethical approval: The study was approved by the ethics committee of University Hospital (KAEK / 2011/168).

\section{STATISTICAL ANALYSIS}

Statistical analysis was performed with the IBM SPSS $20.0^{\text {TM }}$ program (SPSS Inc., Chicago, IL, 
USA). Data with normal distribution were stated as mean \pm standard deviation and data not showing normal distribution as median (range) values. Comparisons of independent binary groups with normal distribution were made with the test, ANOVA variance analysis was applied to hypervariable groups. The MannWhitney U test was used to compare two groups of data not showing normal distribution, and over-variant groups. For the comparison of percentages of qualitative data, the Paired chisquare test and $\mathrm{z}$-test were applied. A value of $\mathrm{p}<$ 0.05 was considered statistically significant. Pearson correlation test was used for correlation.

\section{RESULTS}

Of 75 patients included in the study, $42(56 \%)$ were female and $33(44 \%)$ were male. Bone density measurements of the subjects were found to be low compared to the reference values of the DXA device $(p<0.001)$ (Table I).

Table I: Comparison of Bone Density Measurements of 75 Cases with VLBW Aged 5-7 Years That Followed-Up in NICU.

\begin{tabular}{|c|c|c|c|}
\hline & Females & Males & p value \\
\hline L1-L4 BMD $\left(\mathrm{g} / \mathrm{cm}^{2}\right)$ & $0.567 \pm 0.012$ & $0.571 \pm 0.017$ & \\
\hline Reference value & $0.650 \quad(0.624-$ & 0.633 & $<0.001$ \\
\hline $\begin{array}{l}\text { Femur neck BMD } \\
\left(\mathrm{g} / \mathrm{cm}^{2}\right)\end{array}$ & $0.582 \pm 0.012$ & $0.656 \pm 0.018$ & \\
\hline Reference value & $0.660 \quad(0.640-$ & 0.704 & $<0.001$ \\
\hline $\begin{array}{l}\text { Femur total BMD } \\
\left(\mathrm{g} / \mathrm{cm}^{2}\right)\end{array}$ & $0.572 \pm 0.013$ & $0.629 \pm 0.017$ & \\
\hline Reference value & $\begin{array}{ll}0.645 & (0.630- \\
0.660) & \end{array}$ & $\begin{array}{l}0.677)(0.649- \\
0.705)\end{array}$ & $<0.001$ \\
\hline TB BMD $\left(\mathrm{g} / \mathrm{cm}^{2}\right)$ & $0.769 \pm 0.084$ & $0.774 \pm 0.010$ & \\
\hline Reference value & $\begin{array}{l}0.806 \quad 0.793- \\
0.819)\end{array}$ & $\begin{array}{l}0.800 \\
0.820)\end{array}$ & $<0.001$ \\
\hline TBLH BMD $\left(\mathrm{g} / \mathrm{cm}^{2}\right)$ & $0.586 \pm 0.007$ & $0.599 \pm 0.009$ & \\
\hline Reference value & $\begin{array}{ll}0.648 & (0.622- \\
0.674) & \end{array}$ & $\begin{array}{l}0.631 \\
0.662)\end{array}$ & $<0.001$ \\
\hline
\end{tabular}

According to the $\mathrm{Z}$ score normal and -2.0 (low bone density by chronological age) bone density measurements of male and female cases were summarized in Table II. According to the L1-L4 $\mathrm{Z}$ score, \% 78.66 (59) had normal bone density, and $21.33 \%$ (16) had low bone density (Table III). 
Table II: Relationship of Gender with bone density measurements of 75 Cases with VLBW Aged 5-7 Years That Followed-Up in NICU.

\begin{tabular}{|c|c|c|c|}
\hline & Females & Males & $p$-value \\
\hline L1-L4 Z score & $-1,050 \pm 1,64$ & $-0,887 \pm 1,99$ & 0.534 \\
\hline TB Z score & $-1,100 \pm 0,23$ & $-0,533 \pm 0,177$ & 0.055 \\
\hline TBLH Z score & $-1,211 \pm 0,121$ & $-0,806 \pm 0,175$ & 0.062 \\
\hline Femur neck Z score & $-1,250 \pm 0,188$ & $-0,684 \pm 0,226$ & 0.057 \\
\hline Femur total Z score & $-1,226 \pm 0,216$ & $-0,551 \pm 0,174$ & 0.018 \\
\hline L1-L4 BMD $\left(\mathrm{g} / \mathrm{cm}^{2}\right)$ & $0,567 \pm 0,012$ & $0,571 \pm 0,017$ & 0.843 \\
\hline TB BMD $\left(\mathrm{g} / \mathrm{cm}^{2}\right)$ & $0,769 \pm 0,084$ & $0,774 \pm 0,010$ & 0.674 \\
\hline TBLH BMD $\left(\mathrm{g} / \mathrm{cm}^{2}\right)$ & $0,586 \pm 0,007$ & $0,599 \pm 0,009$ & 0.313 \\
\hline Femur neck BMD $\left(\mathrm{g} / \mathrm{cm}^{2}\right)$ & $0,582 \pm 0,012$ & $0,656 \pm 0,018$ & 0.001 \\
\hline Femur total BMD $\left(\mathrm{g} / \mathrm{cm}^{2}\right)$ & $0,572 \pm 0,013$ & $0,629 \pm 0,017$ & 0.012 \\
\hline L1-L4 BMC (g) & $13,357 \pm 0,423$ & $14,309 \pm 0,660$ & 0.230 \\
\hline TB BMC (g) & $576,10 \pm 177$ & $625,93 \pm 266$ & 0.125 \\
\hline TBLH BMC & $336,34 \pm 13,47$ & $372,76 \pm 21,83$ & 0.313 \\
\hline Femur neck BMC (g) & $0,94 \pm 0,37$ & $1,04 \pm 0,05$ & 0.117 \\
\hline Femur total BMC (g) & $5,38 \pm 0,264$ & $6,08 \pm 0,338$ & 0.115 \\
\hline L1-L4 Z score $(<-2)$ & $10(\%$ 23.8) & $6(18.1 \%)$ & $\begin{array}{l}0.2 \\
48\end{array}$ \\
\hline TB Z score $(<-2)$ & $6(\% 14.3)$ & $1(3 \%)$ & $\begin{array}{l}0.0 \\
23\end{array}$ \\
\hline TBLH Z score $(<-2)$ & $6(\% 14.3)$ & $4(12.1 \%)$ & 0.248 \\
\hline Femur neck $Z$ score $(<-2)$ & $11(26.2 \%)$ & $4(12.1 \%)$ & $\begin{array}{l}0.0 \\
03\end{array}$ \\
\hline $\begin{array}{l}\text { Total Femur Z score }(<- \\
\text { 2) }\end{array}$ & $11(26.2 \%)$ & $1(3 \%)$ & $\begin{array}{l}0.0 \\
01\end{array}$ \\
\hline
\end{tabular}

BMD: bone mineral density BMC: bone mineral content TB: total bone, TBLH: total body less head
Table III: Comparison of Characteristics of NICU Hospitalization According to the Results of Bone Density Measurements of 75 Cases with VLBW Aged 5-7 Years Old.

\begin{tabular}{|c|c|c|c|}
\hline & $\begin{array}{l}\text { L1 - L4 } \\
\text { Normal }\end{array}$ & $\begin{array}{l}\text { L1-L4 } \\
\text { Low }\end{array}$ & $\mathrm{p}$ value \\
\hline Birth weight (gr) & $1199 \pm 31.77$ & $1089 \pm 47.32$ & 0.058 \\
\hline Birth week & $30.28 \pm 0.31$ & 29.81 & 0,422 \\
\hline PPV & $21(35.6 \%)$ & $6(37.5 \%)$ & 1,000 \\
\hline Preeclampsia & $24(40.7 \%)$ & $4(25 \%)$ & 0,383 \\
\hline Chorioamnionitis & $12(20.3 \%)$ & 0 & 0.059 \\
\hline Prenatal steroid & 46 (78\%) & $12(75 \%)$ & 0.749 \\
\hline SGA & $13(22 \%)$ & $5(31.2 \%)$ & 0.513 \\
\hline RDS & $45(76.3 \%)$ & $13(81.2 \%)$ & 0.668 \\
\hline Mechanical Ventilation & $50(84.7 \%)$ & $15(93.8 \%)$ & 0.449 \\
\hline Sepsis & $37(62.7 \%)$ & $10(62.5 \%)$ & 1.000 \\
\hline PDA & $7(11.9 \%)$ & $2(12.5 \%)$ & 1.000 \\
\hline NEC & $17(28.8 \%)$ & $2(12.5 \%)$ & 0.060 \\
\hline $\mathrm{ICH}$ & $46(78 \%)$ & $11(68.8 \%)$ & 0.513 \\
\hline Inhaled steroid & $24(40.7 \%)$ & $6(37.5 \%)$ & 1.000 \\
\hline Systemic steroid & $11(18.6 \%)$ & $2(12.5 \%)$ & 0.784 \\
\hline ROP & $6(10.2 \%)$ & $2(12.5 \%)$ & 0.676 \\
\hline Theophylline and caffeine & $31(52.5 \%)$ & $7(43.8 \%)$ & 0.068 \\
\hline Breast milk (month) & $6.02 \pm 1.09$ & $9.77 \pm 2.76$ & 0.215 \\
\hline Vitamin D (month) & $14.46 \pm 0.09$ & $17.24 \pm 2.16$ & 0.209 \\
\hline Formula use (month) & $12.03 \pm 2.08$ & $14.74 \pm 2.66$ & 0.314 \\
\hline Current height $(\mathrm{cm})$ & $111.33 \pm 0.95$ & $107.0 \pm 1.03$ & 0.003 \\
\hline Current weight (kg) & $19.80 \pm 0.62$ & $16.5 \pm 0.40$ & 0.000 \\
\hline Current BMI & $15.98 \pm 0.32$ & $14.48 \pm 0.20$ & 0.000 \\
\hline Total & $59(78.66 \%)$ & $16(21.33 \%)$ & \\
\hline
\end{tabular}

PPV: positive pressure ventilation, SGA: Small for gestational age, RDS: respiratory distress syndrome, PDA: patent ductus arteriosus, NEC: necrotizing enterocolitis, ICH: intracranial hemorrhage, ROP: retinopathy of prematurity, BMI: Body mass index 
The femur total Z score $(\mathrm{p}=0.018)$, femur neck BMD ( $\mathrm{p}=0.001)$ and femur total BMD ( $\mathrm{p}=$ 0.012) measurements were significantly lower in females than in male patients (Figure 1).

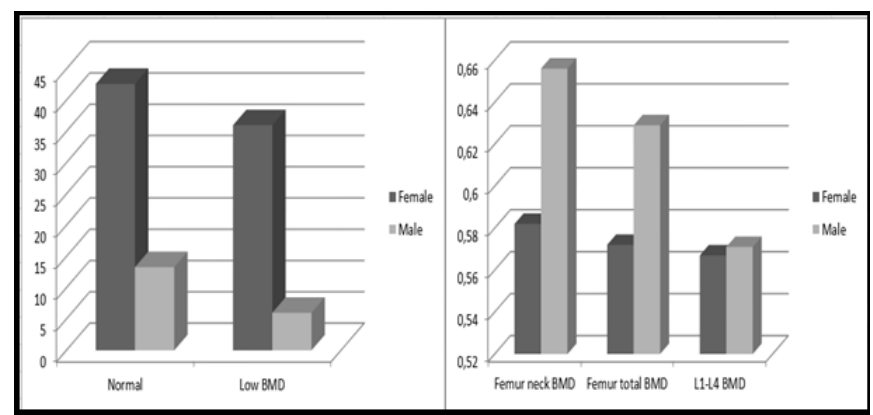

Figure 1: Classification According to Gender and Bone Density Measurement of 75 Cases with VLBW Aged 5-7 Years Old That Followed-Up in NICU and Relationship Between Femur Neck, Total Femur and L1-L4 BMD Values.

There were statistically significant differences only in current height, weight, BMI values when prenatal, natal and postnatally followed-up parameters of two groups with low and normal bone density are compared (Table III).

When bone mineral density measurements (TB, TBLH, L1-L4, femur neck and femur total BMD, BMC and $\mathrm{Z}$ score) of the cases were compared with the prenatal, natal and postnatal parameters no statistically significant difference was found (Table III).

When small for gestational age (SGA) and appropriate for gestational age (AGA) are compared according to the application of positive pressure ventilation (PPV) and/or mechanical ventilation, and for the history of PDA, NEC, ROP in intensive care unit follow-ups no statistical significance was found.

In a cluster receiving postpartum steroid the total body BMD value was significantly lower ( $p$ $=0.021$ ) than the cluster non-steroid group.

When the measurements of bone density of the patients who received only breastmilk (femur neck BMD $0.662 \pm 0.025$ ) for the first six months were compared with those who received only formula (femur neck BMD 0.598 \pm 0.016 ) for the first six months, those who received the breastmilk were found to be statistically significantly higher $(p=0.034)$ (Figure 2$)$.

Femur neck BMD (gr/cm2)

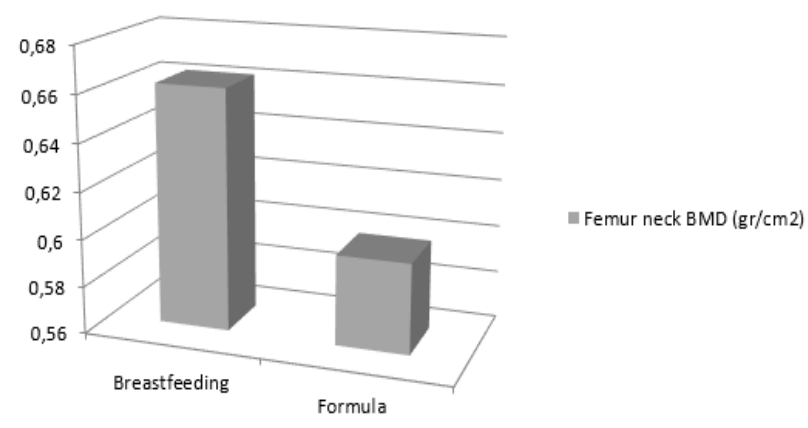

Figure 2: The Relationship of BMI, Weight, Height Percentiles with L1-L4 BMD of 75 Cases with VLBW that Followed-Up in NICU.

In children going to school ( $\mathrm{n}=34) \mathrm{L} 1-\mathrm{L} 4 \mathrm{Z}$ score, L1-L4 BMD, L1-L4 BMC, TB BMD, TB BMC, TBLH $\mathrm{Z}$ score, TBLH BMD, TBLH BMC, femur neck BMD, femur neck BMC, total femur BMD, total femur BMC values were significantly higher than who did not attend to school $(\mathrm{p}=0.040, \mathrm{p}$ $<0.001, \mathrm{p}<0.001, \mathrm{p}=0.009, \mathrm{p}<0.001, \mathrm{p}=$ $0.041, \mathrm{p}=0.001, \mathrm{p}=0.001, \mathrm{p}=0.012, \mathrm{p}=0.004$ ， $\mathrm{p}=0.012$, respectively).

Vitamin D, calcium, phosphorus, ALP and PTH levels that affect bone mineral density also was evaluated. There was no significant difference in BMD levels between patients $(p=0.576, p$ $=.356, \quad \mathrm{p}=0.274, \mathrm{p}=0.255, \mathrm{p}=0.341$, respectively).

There was a correlation between femur neck $\mathrm{Z}$ score ( $\mathrm{r}$ : $0.259 \mathrm{p}=0.028), \mathrm{BMC}(\mathrm{r}: 0.276 \mathrm{p}=$ 0.019), BMD ( $r: 0.260 p=0.027$ ), femur total $Z$ score ( $\mathrm{r}: 0.259 \mathrm{p}=0.028$ ), BMD ( $\mathrm{r}: 0.258 \mathrm{p}=$ 0.028 ) and milk consumption in the last $2-3$ weeks of the cases.

When the current height (except total body $\mathrm{Z}$ score), weight, BMI increment and bone density measurements were compared, significant differences were found in terms correlation between them (Table IV). There was a statistically significant difference when all bone 
density parameters were compared with current height, weight and BMI percentiles smaller and greater than 10th percentile.

Table IV Evaluation of Correlation Analysis

\begin{tabular}{|c|c|c|c|c|c|c|c|c|c|c|c|}
\hline & \begin{tabular}{|l} 
Birth \\
weight
\end{tabular} & $\begin{array}{l}\text { Birth } \\
\text { week }\end{array}$ & $\begin{array}{l}\text { Hospitalizatio } \\
\text { n duration }\end{array}$ & TPN & $\begin{array}{l}\text { Breast- } \\
\text { feeding } \\
\text { time }\end{array}$ & $\begin{array}{l}\text { Formula } \\
\text { feeding } \\
\text { period }\end{array}$ & $\begin{array}{l}\text { Vitamin } \\
\text { D use } \\
\text { period }\end{array}$ & Height & Weight & BMI & $\begin{array}{l}\text { Daily milk } \\
\text { consumption }\end{array}$ \\
\hline $\begin{array}{ll}\text { L1-L4 } & \text { Z } \\
\text { score } & \end{array}$ & $\begin{array}{l}\mathrm{r}: 0.520 \\
\mathrm{p}: 0.658\end{array}$ & $\begin{array}{l}\mathrm{r}: 0.072 \\
\mathrm{p}: 0.540\end{array}$ & $\begin{array}{l}\mathrm{r}: 0.022 \\
\mathrm{p}: 0.852\end{array}$ & $\begin{array}{l}\mathrm{r}: 0.002 \\
\mathrm{p}: 0.986\end{array}$ & $\begin{array}{l}\mathrm{r}: 0.042 \\
\mathrm{p}: 0.719\end{array}$ & $\begin{array}{l}\mathrm{r}: 0.091 \\
\mathrm{p}: 0.441\end{array}$ & $\begin{array}{l}\mathrm{r}: 0.009 \\
\mathrm{p}: 0.940\end{array}$ & $\begin{array}{l}r: 0.490 \\
p: 0.000\end{array}$ & $\begin{array}{l}r: 0.590 \\
p: 0.000\end{array}$ & $\begin{array}{l}r: 0.410 \\
p: 0.000\end{array}$ & $\begin{array}{l}\mathrm{r}: 0.133 \\
\mathrm{p}: 0.254\end{array}$ \\
\hline $\begin{array}{ll}\text { TB } & \text { Z } \\
\text { score } & \end{array}$ & $\begin{array}{l}\mathrm{r}: 0.140 \\
\mathrm{p}: 0.232\end{array}$ & $\begin{array}{l}\mathrm{r}: 0.163 \\
\mathrm{p}: 0.162\end{array}$ & $\begin{array}{l}\mathrm{r}: 0.004 \\
\mathrm{p}: 0.972\end{array}$ & $\begin{array}{l}\mathrm{r}: 0.540 \\
\mathrm{p}: 0.647\end{array}$ & $\begin{array}{l}\mathrm{r}: 0.001 \\
\mathrm{p}: 0.992\end{array}$ & $\begin{array}{l}\text { r:0.114 } \\
\text { p:0.329 }\end{array}$ & $\begin{array}{l}\mathrm{r}: 0.082 \\
\mathrm{p}: 0.483\end{array}$ & $\begin{array}{l}r: 0.277 \\
p: 0.16\end{array}$ & $\begin{array}{l}r: 0.407 \\
p: 0.000\end{array}$ & $\begin{array}{l}r: 0.351 \\
p: 0.002\end{array}$ & $\begin{array}{l}\mathrm{r}: 0.121 \\
\mathrm{p}: 0.321\end{array}$ \\
\hline $\begin{array}{l}\text { L1-L4 } \\
\text { BMD }\end{array}$ & $\begin{array}{l}\mathrm{r}: 0.044 \\
\mathrm{p}: 0.708\end{array}$ & $\begin{array}{l}\mathrm{r}: 0.025 \\
\mathrm{p}: 0.829\end{array}$ & $\begin{array}{l}\mathrm{r}: 0.018 \\
\mathrm{p}: 0.876\end{array}$ & $\begin{array}{l}\mathrm{r}: 0.025 \\
\mathrm{p}: 0.831\end{array}$ & $\begin{array}{l}\mathrm{r}: 0.098 \\
\mathrm{p}: 0.401\end{array}$ & $\begin{array}{l}\mathrm{r}: 0.013 \\
\mathrm{p}: 0.910\end{array}$ & $\begin{array}{l}\mathrm{r}: 0.033 \\
\mathrm{p}: 0.782\end{array}$ & $\begin{array}{l}r: 0.577 \\
p: 0.000\end{array}$ & $\begin{array}{l}r: 0.603 \\
p: 0.000\end{array}$ & $\begin{array}{l}r: 0.320 \\
p: 0.005\end{array}$ & $\begin{array}{l}\mathrm{r}: 0.0 .88 \\
\mathrm{p}: 0.453\end{array}$ \\
\hline $\begin{array}{l}\text { L1-L4 } \\
\text { BMC }\end{array}$ & $\begin{array}{l}\mathrm{r}: 0.168 \\
\mathrm{p}: 0.149\end{array}$ & $\begin{array}{l}\mathrm{r}: 0.017 \\
\mathrm{p}: 0.817\end{array}$ & $\begin{array}{l}\mathrm{r}: 0.103 \\
\mathrm{p}: 0.378\end{array}$ & $\begin{array}{l}\mathrm{r}: 0.690 \\
\mathrm{p}: 0.554\end{array}$ & $\begin{array}{l}\mathrm{r}: 0.094 \\
\mathrm{p}: 0.422\end{array}$ & $\begin{array}{l}\mathrm{r}: 0.083 \\
\mathrm{p}: 0.481\end{array}$ & $\begin{array}{l}\mathrm{r}: 0.018 \\
\mathrm{p}: 0.880\end{array}$ & $\begin{array}{l}\text { r:0.775 } \\
p: 0.000\end{array}$ & $\begin{array}{l}r: 0.733 \\
p: 0.000\end{array}$ & $\begin{array}{l}r: 0.308 \\
p: 0.007\end{array}$ & $\begin{array}{l}\mathrm{r}: 0.213 \\
\mathrm{p}: 0.066\end{array}$ \\
\hline TB BMD & $\begin{array}{l}\mathrm{r}: 0.018 \\
\mathrm{p}: 0.313\end{array}$ & $\begin{array}{l}\mathrm{r}: 0.123 \\
\mathrm{p}: 0.293\end{array}$ & $\begin{array}{l}\mathrm{r}: 0.031 \\
\mathrm{p}: 0.791\end{array}$ & $\begin{array}{l}\mathrm{r}: 0.130 \\
\mathrm{p}: 0.267\end{array}$ & $\begin{array}{l}\mathrm{r}: 0.053 \\
\mathrm{p}: 0.649\end{array}$ & $\begin{array}{l}\mathrm{r}: 0.017 \\
\mathrm{p}: 0.882\end{array}$ & $\begin{array}{l}\mathrm{r}: 0.101 \\
\mathrm{p}: 0.388\end{array}$ & $\begin{array}{l}p: 0.356 \\
p: 0.002\end{array}$ & $\begin{array}{l}r: 0.447 \\
p: 0.000\end{array}$ & $\begin{array}{l}r: 0.306 \\
p: 0.008\end{array}$ & $\begin{array}{l}\mathrm{r}: 0.133 \\
\mathrm{p}: 0.254\end{array}$ \\
\hline TB BMC & $\begin{array}{l}\mathrm{r}: 0.116 \\
\mathrm{p}: 0.321\end{array}$ & $\begin{array}{l}\mathrm{r}: 0.080 \\
\mathrm{p}: 0.692\end{array}$ & $\begin{array}{l}\mathrm{r}: 0.046 \\
\mathrm{p}: 0.698\end{array}$ & $\begin{array}{l}\mathrm{r}: 0.026 \\
\mathrm{p}: 0.823\end{array}$ & $\begin{array}{l}\text { r:0.142 } \\
\text { p:0.226 }\end{array}$ & $\begin{array}{l}\mathrm{r}: 0.065 \\
\mathrm{p}: 0.578\end{array}$ & $\begin{array}{l}\mathrm{r}: 0.006 \\
\mathrm{p}: 0.960\end{array}$ & $\begin{array}{l}\text { r:0.786 } \\
p: 0.000\end{array}$ & $\begin{array}{l}r: 0.811 \\
p: 0.000\end{array}$ & $\begin{array}{l}r: 0.418 \\
p: 0.000\end{array}$ & $\begin{array}{l}\mathrm{r}: 0.222 \\
\mathrm{p}: 0.056\end{array}$ \\
\hline
\end{tabular}

TB BMC: Total Body bone mineral content, TB BMD: total bone mineral density, TPN: Total parenteral nutrition

\section{DISCUSSION}

In recent years, osteopenia has become an important topic in childhood. One of the risk factors causing osteopenia is premature birth ${ }^{15}$. In the literature, in the evaluations of bone mineralization of preterm infants in childhood age group osteopenia rates are not given but BMD and BMC ratios of these cases were evaluated. In this study, in comparison of 5-7 years children born preterm and VLBW with healthy children of the same age, the bone densities according to L1-L4 Z score was low in $21.33 \%$.

Bone density measurement values of our cases were lower than the reference values of DXA device. Breukhoven et al. ${ }^{17}$ reported in their study of 18-24 years old patients with preterm birth that preterm birth did not affect their adult bone health. In the study of Erlanson et al. ${ }^{18}$, in children between the ages of 8-15 years proximal femur BMC value was significantly lower in males with preterm birth, but there was no difference between groups when age, maturity, weight, physical activity and nutrition were added into consideration. However, Bowden et al. ${ }^{15}$ showed in their study that children with preterm birth had low lumbar vertebrae BMC values at the age of 8 years. In the study of Weiler et al. ${ }^{19}$ children born with low birth weight at their 16-19 years, total body, lumbar and total femur BMC values were reported to be lower than children with born at term. Xie et al. ${ }^{20}$ showed that low BMD at any site was observed in 53\% of adults born preterm versus $28 \%$ of full-term controls.

When the total femur Z score, femur neck BMD, total femur BMD values of females were compared, it was found that they were significantly lower than the males; it might be related to the lower BMI and weight of females.

In a group receiving postoperative systemic steroids TB BMD had lower values than the nonsteroid group; it may be associated with negative effects of steroid use and chronic lung diseases on bone health. In the study of Eeloo et al. ${ }^{16}$, similar to our study, significantly low 
lumbar spinal bone mineral density measurements were found according to DXA evaluation when children aged 5-8 years with VLBW who received steroid therapy due to chronic lung disease compared with preterm control group not receiving steroid therapy.

In the comparison of cases receiving only breastmilk or formula in the first six months, the femur BMD value was significantly higher in the group receiving only breastmilk. In one study, 5year-old children with VLBW with breast milk after birth have been reported to have higher bone mineral content in wrists. ${ }^{21}$ Fewtrel et al. ${ }^{22}$ reported in their study of 12-years old children with preterm birth that there was no correlation between total body BMC and early life feeding. Christmann et al. ${ }^{23}$ were found that at 9 to 10 years the mean bone mass SDS measured for total body and lumbar vertebrae was within the normal range and seemed not related to nutritional intake.

In children attended school, L1-L4 BMD, L1-L4 BMC, TB BMD, TB BMC values were significantly higher than who did not attend school. Cells that are sensitive to mechanical stress needed to be stimulated for bone production. For this reason, physical movements such as running, jumping, rope jumping and gymnastic movements which make the bone surfaces stretch, are of great importance especially in childhood and adolescence period where bone formation is accelerated. Therefore, there is an absolute need to improve the duration and quality of physical education classes in schools ${ }^{24}$.

One of the reasons why it is hard to determine the effect of preterm birth on bone mineralization is the effect of current body mass of the person ${ }^{25}$. In this study, weight, BMI and height of the cases were within normal ranges according to norms of healthy Turkish children of their age ${ }^{26}$. Current weight and BMI of females were found to be lower than males. Erlandson et al. ${ }^{18}$ in their study found that preterm females had lower weight when compared to males and control group.

In this study, the correlation was found between height, weight, BMI and bone measurements. As in the study by Kurl et al. ${ }^{6}$, significant variables between BMC, BMD and $\mathrm{Z}$ scores were due to current weight, height and BMI of the cases. The most important determinants of the effects of preterm birth on bone mineralization are current weight, height and $\mathrm{BMI}^{24}$.

\section{CONCLUSION}

Osteoporosis is a public health problem that has an increasing importance in both developed and developing countries. The fact that VLBW and premature children cannot surviving the last trimester of pregnancy, negatively affects bone health both postpartum and in childhood. In our study, it was shown that bone diseases, which are one of the increasing complications in VLBW and preterm infants, affect growth and bone mineralization in postpartum and long term. We determined the effects of the diseases seen in VLBW and premature births, drugs used in the treatment and nutrition, current anthropometric measurements (height, weight and BMI) on bone health. VLBW and premature births should be monitored closely until the adolescence period in order to reduce the risk of decrement either in bone mineralization and peak bone mass in the adult period.

\section{FUNDING}

The author declares that he received no financial support; there is no conflict of interest for authorship, and publication of this research.

Ethics Committee Approval: The local research and ethics committee approved the study protocol, and the study was conducted following the ethical principles described by the Declaration of Helsinki.

Declaration of Conflicting Interests: The authors declare that they have no conflict of interest. 
Financial Disclosure: No financial support was received.

\section{REFERENCES}

1. Katar S., Devecioğlu C. Outcome of Very Low Birth Weight Infants in Neonatal Care Unit of Dicle University Faculty of Medicine. Dicle Med J 2006; 33 : 248-51.

2. Ukarapong S, Venkatarayappa SKB, Navarrete C, Berkovitz G. Risk factors of metabolic bone of prematurity. Early Hum Dev. 2017; 112: 29-34.

3. Faulkner RA, Bailey DA, Drinkwater DT, McKay HA, Arnold C, Wilkinson AA. Bone densitometry in Canadian children 8 - 17 years of age. Calcif Tissue Int. 1996; 59:344-51.

4. Körnmann MN, Christmann V, Charlotte J, et al. Growth and Bone Mineralization of Very Preterm Infants at Term Corrected Age in Relation to Different Nutritional Intakes in the Early Postnatal Period. Nutrients. 2017; 9: 1318.

5. Cooper C, Cawley M, Bhalla A, et al. Childhood growth, physical activity, and peak bone mass in women. J Bone Miner Res. 1995; 10: 940-7.

6. Kurl K, Heinonen K, Länsimies E, Launiala K. Determinants of bone mineral density in prematurely born children aged 6-7 years Acta Paediatr. 1998; 87:650-3.

7. Armstrong C, Chan GM, Moyer-Mileur L, Archuleta M. Seven year follow-up of premature infants' bone mineralization (abstract). Pediatr Res. 1997; 41: 190.

8. Rubinacci A, Sirtori P. Moro G, Galli L, Minoli I, Tessari L. Is there an impact of birth weight and early life on bone mineral contect in premature born infants and children? Acta Paediatr. 1993; 82: 7113.

9. Faulkner RA, Bailey DA, Drinkwater DT, McKay HA, Arnold C, Wilkinson AA. Bone densitometry in Canadian children 8 - 17 years of age. Calcif Tissue Int. 1996; 59:344-51.

10. Faienza MF, D'Amato E, Natale MP, et al. Metabolic Bone Disease of Prematurity: Diagnosis and Management. Front Pediatr. 2019; 7: 143.
11. So KW, Ng PC: Treatment and prevention of neonatal osteopenia. Current Paediatrics.2005; 15: 106-13.

12. Sharp M. Bone disease of prematurity. Early Hum Dev. 2007; 83: 653-58.

13. Figueras-Aloy J, Álvarez-Domínguez E, PérezFernández JM, et al. Metabolic bone disease and bone mineral density in very preterm infants. J Pediatr. 2014; 164: 499-504.

14. Seeman E, Wahner HW, Offord KP, et al. Differential effects of endocrine dysfunction on the axial and the appendicular skeleton. J Clin Invest. 1982; 69: 1302-9.

15. Bowden LS, Jones CA, Ryan SW. Bone mineralization in ex- preterm infants aged 8 years. Eur J Pediatr. 1999; 158: 658-61.

16. Eelloo JA, Roberts SA, Emmerson AJ, et al. Bone status of children aged 5-8 years, treated with dexamethasone for chronic lung disease of prematurity. Arch Dis Child Fetal Neonatal Ed. 2008; 93: 222-24.

17. Breukhoven PE, Leunissen WJ, Kort WK S, et al. Preterm birth does not affect bone mineral density in young adults. Eur J Endocrinol. 2011; 164: 13338.

18. Erlandson MC, Sherar LB, Baxter-Jones AD, et al. Premature Birth and Adolescent Bone MineralContent. Am J Perinatol. 2011; 28:157-63.

19. Weiler HA, Yuen CK, Seshia MM. Growth and bone mineralization of young adults weighing less than $1500 \mathrm{~g}$ at birth. Early Hum Dev. 2002; 67: 10112.

20. Xie LF, Alos N, Cloutier A, et al. The long-term impact of very preterm birth on adult bone mineral density. Bone Rep. 2018; 10: 100189.

21. Hovi P, Andersson S, Ja"rvenpa"a AL, et al. Decreased Bone Mineral Density in Adults Born with Very Low Birth Weight: A Cohort Study. PLoS Med. 2009; 6: 1000135.

22. Fewtrell MS, Prentice A, Jones SC, et al. Bone mineralization and turnover in premature infants at 8-12 years of age: the effect of early diet. J Bone Miner Res 1999; 14: 810-20. 
23. Christmann V, van der Putten ME, Rodwell L, et al. Effect of early nutritional intake on long-term growth and bone mineralization of former very low birth weight infants. Bone. 2018; 108: 89-97.

24. Kroger H, Kotaniemi A, VainoP, Alhava E. Bone dansitometry the spine and femur in children by dual-energy X-ray absorptiometry. Bone Miner. 1992; 17: 75-85.

25. Awad HA, Farid TM, Khafagy SM, Nofal RI. Bone Mineral Content Measured by DEXA Scan in Preterm Neonates Receiving Total Parentral Nutrition with and without Phosphorus Supplementation. Pak J Biol Sci. 2010; 13: 891-95.
26. Neyzi O, Bundak R, Gökçay G, et al. Reference Values for Weight, Height, Head Circumference, and Body Mass Index in Turkish Children. J Clin Res Pediatr Endocrinol. 2015; 7: 280-93. 